\title{
The Importance of Soil Health for Residential Landscapes ${ }^{1}$
}

\author{
Sally Scalera, Alexander J. Reisinger, and Mary Lusk²
}

The purpose of this fact sheet is to educate home gardeners, residential landscape professionals, and employees caring for green areas, including golf courses, about the importance of soil health and practices for achieving healthy soil. Gardeners and landscapers are all very aware of the disease-causing fungi and root-harming nematodes, but they are often unaware that a wide variety of beneficial organisms live in the soil. For additional information on evaluating soil health, refer to the EDIS document Tools for Evaluating Soil Health.

When soil is considered in residential landscapes, it is often thought of in terms of its $\mathrm{pH}$, drainage, and nutrient content. However, soil is more complex than its measurable chemical and physical properties. Healthy soils also contain organic matter and a diverse soil food web (SFW), or community of organisms, which interact with each other and the soil environment. This community consists of various micro- and macroorganisms such as fungi, bacteria, arthropods, nematodes, and other organisms listed here.

Soil health is defined by the United States Department of Agriculture-Natural Resources Conservation Service (USDA-NRCS) as the capacity of the soil to function as a vital living ecosystem that can sustain plants and animals, including humans. Soil is an ecosystem, and a sustainable way to produce healthy plants is to focus on soil health and adopt practices to encourage a healthy soil environment. Examples of such practices include reducing soil disturbance, keeping the soil covered with living plants or mulches, growing a variety of plants throughout the year to preserve the organic matter, and protecting the soil food web by minimizing chemical inputs to the soil. The primary driver of a healthy soil is a thriving soil food web represented by a diversity of organisms that produce or consume energy, nutrients, and other materials. Soil food webs are comprised of a variety of organisms including invertebrates, plant roots, and microbial organisms. These beneficial microbes carry out nutrient cycling (where nutrients are continually made available to the plants by the activities of the microbes), out-compete pathogenic microbes for resources and/or prey on pathogens, help in the production of organic matter, and improve soil structure. A healthy soil food web living in fertile soil, with the proper amounts of all nutrients, allows the soil to grow optimally healthy and nutritious plants to support healthy animals (including humans). It also protects water quality through its role in building soil organic matter, increasing internal nutrient cycling, reducing fertilizer requirements, and reducing nutrient losses via stormwater runoff and/or leaching via increased water holding capacity.

1. This document is SL450, one of a series of the Department of Soil and Water Sciences, UF/IFAS Extension. Original publication date April 2019. Visit the EDIS website at https://edis.ifas.ufl.edu for the currently supported version of this publication.

2. Sally Scalera, urban horticulture agent, UF/IFAS Extension Brevard County; A. J. Reisinger, assistant professor, Department of Soil and Water Sciences; and Mary Lusk, assistant professor, Department of Soil and Water Sciences, UF/IFAS Gulf Coast Research and Education Center; UF/IFAS Extension, Gainesville, FL 32611.

The Institute of Food and Agricultural Sciences (IFAS) is an Equal Opportunity Institution authorized to provide research, educational information and other services only to individuals and institutions that function with non-discrimination with respect to race, creed, color, religion, age, disability, sex, sexual orientation, marital status, national origin, political opinions or affiliations. For more information on obtaining other UF/IFAS Extension publications, contact your county's UF/IFAS Extension office. 


\section{The Soil Food Web}

Productive soil is alive with billions of microbial organisms (for example, bacteria and fungi) per gram and over 4 billion microbial organisms in just a teaspoon of soil (Tugel et al., 2000). The primary components of the soil food web include fungi, bacteria, protozoa, nematodes, and microarthropods.

Plants, when growing in areas without external resource inputs (i.e., fertilizers, water, etc.) supplied by humans, will share some of their carbohydrates/sugars with the microbial community by releasing them from their roots to attract soil microbes. These root exudates, released in the rhizosphere (the area of soil immediately surrounding the roots), supply the soil microbes with food, and the microbes in turn supply the plant with nutrients such as nitrogen or phosphorus. The main microorganisms of the soil food web include the following:

Fungi are the only microbe that can break down lignin, the compound that gives wood its rigidity. Saprophytic fungi decompose dead wood and other plant matter, thereby adding organic matter to the soil. Another important group of fungi are the mycorrhizae, which form a beneficial relationship with plant roots. Mycorrhizae fungi can be divided into endomycorrhizae, which send their hyphae (branching microscopic filaments produced by a fungus) into the cells of the plant roots, and ectomycorrhizae, which form a protective cover around the roots. The mycorrhizal fungi provide the plant with nutrients, primarily phosphorous, in addition to water. The protective barrier created by ectomycorrhizae are effective against pathogenic fungi, parasitic nematodes, and other disease-causing organisms. Mycorrhizal fungi also play a large role in creating soil structure and moving nutrients and water throughout the soil, as mycorrhizal fungi are capable of spreading throughout the soil and joining the root systems of every plant in an entire forest together. For more information on Mycorrhizae, refer to the Soil Mycorrhizal Course (2015).

Bacteria are another major component of a healthy soil food web, because they move in to break down smaller pieces of wood and other plant material after the fungi have decayed the lignin. Their role in the decay process is as important as the fungi's. Bacteria are single-celled organisms that are much more biologically diverse than fungi. Free-living nitrogen-fixing bacteria live adjacent to plant roots, surviving off root exudates and serving as a source of nitrogen in return. These bacteria live in the rhizosphere or are linked via the mycorrhizal highway. Bacteria are responsible for most of the cycling of nitrogen, carbon, and sulfur within soils.

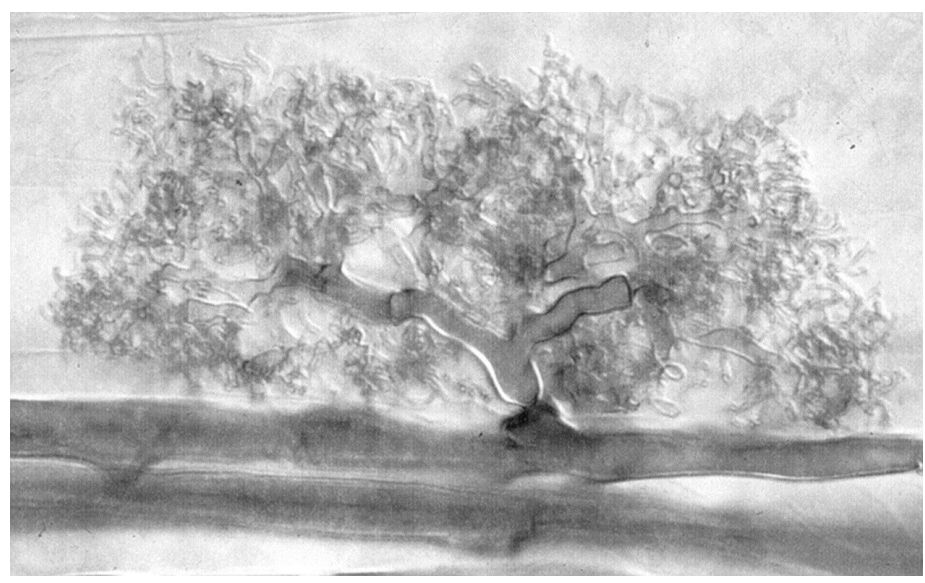

Figure 1. Soil fungi.

Credits: Andy Ogram, UF/IFAS

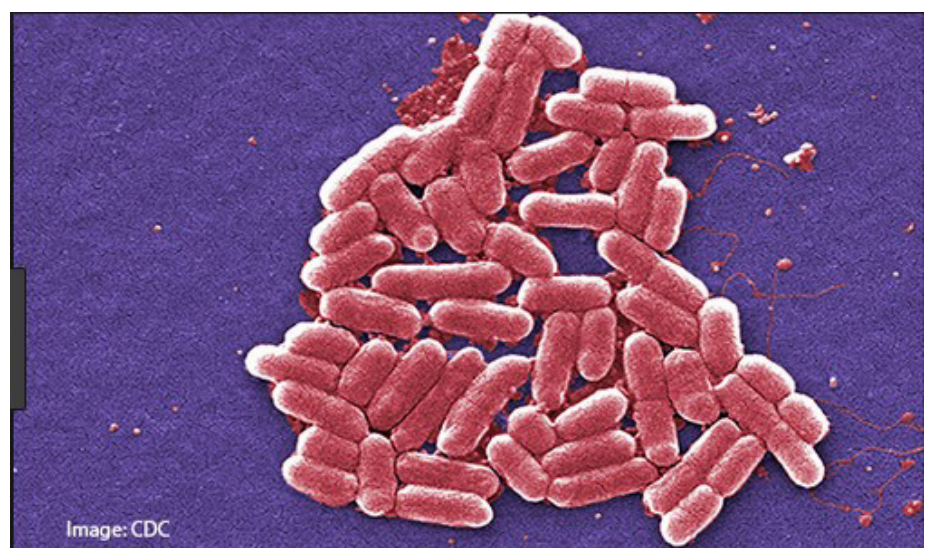

Figure 2. Soil bacteria.

Credits: US Centers for Disease Control

Microarthropods are animals with an exoskeleton (a hard, external covering of the body), a segmented body, and jointed appendages. Examples that can be found in the soil include mites, springtails, and acari. They can be either herbivores or predators, and in addition to preying on other microorganisms, they shred organic matter, which helps stimulate microbial activity.

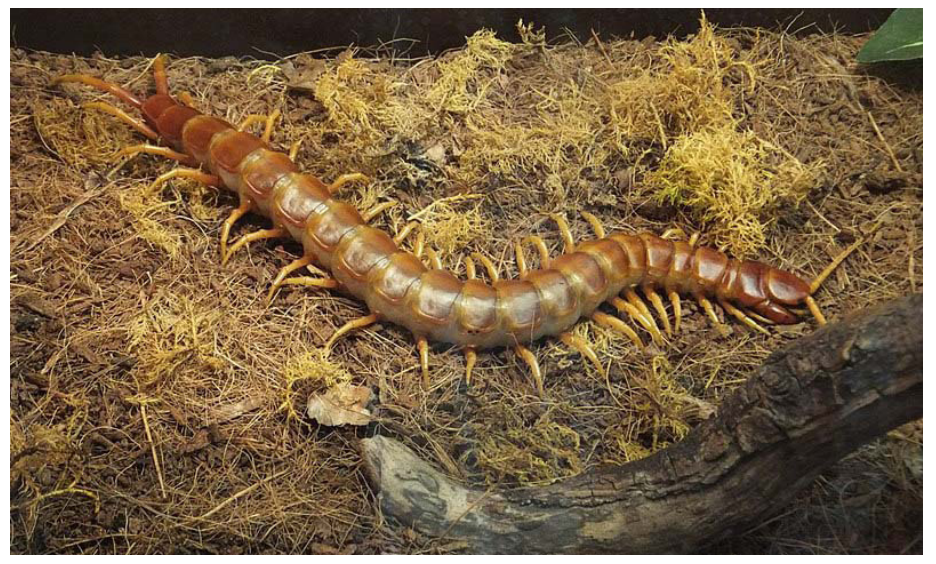

Figure 3. Soil arthropod.

Credits: Wikimedia.org 
Nematodes are microscopic, non-segmented worms. The typical gardener will often associate the term nematodes with the root-feeding nematodes such as root-knot nematodes. In addition to these nematodes, which are commonly thought of as pests, there are fungal- and bacterial-feeding nematodes as well as predatory nematodes. They cycle nutrients and are a food source for other microbes, and some of them consume bacteria and pathogenic fungi, which can suppress disease.

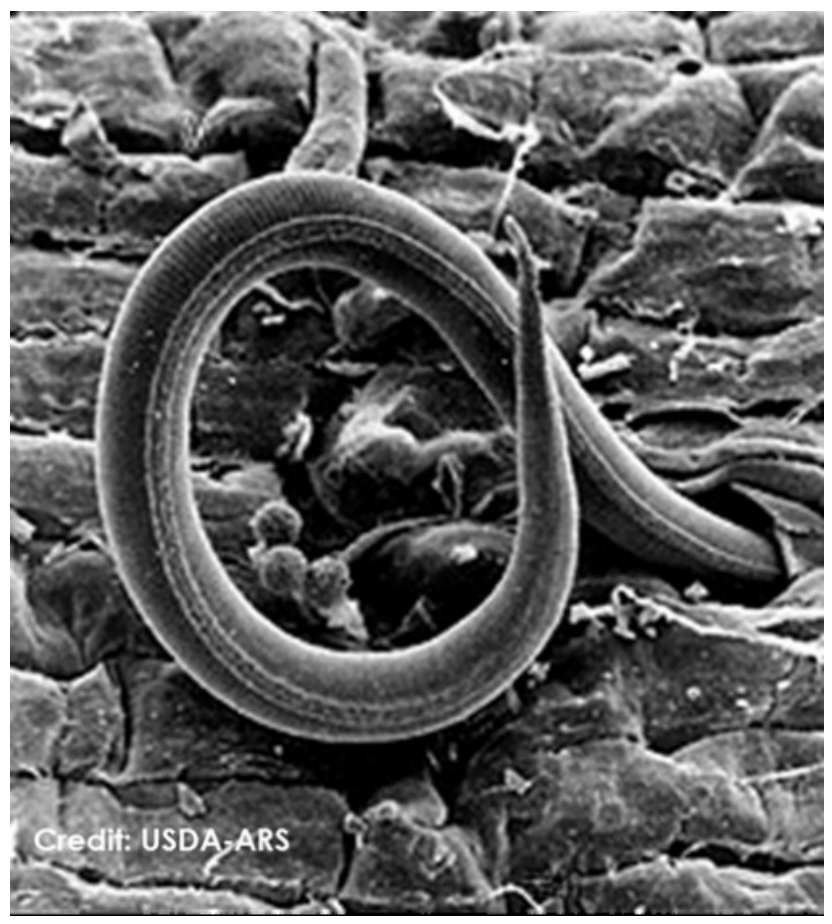

Figure 4. Soil nematode.

Credits: USDA

Protozoa are single-celled organisms (such as amoebae, flagellates, and ciliates) that are larger than bacteria and very mobile in the rhizosphere (region of soil adjacent to plant roots) where all microbes are the most abundant and active. They cycle nutrients, especially nitrogen, when feeding on bacteria (which also regulates bacterial populations) and other protozoa.

The various soil microbes perform different roles. Many fungi and bacteria are important in breaking down organic matter, and their presence in soil holds onto the nutrients so that after their death, the nutrients are made available once again. The other microorganisms-protozoa, beneficial nematodes, and microarthropods-are predatory and help to maintain the levels of nutrients in the rhizosphere that are available to the plants.

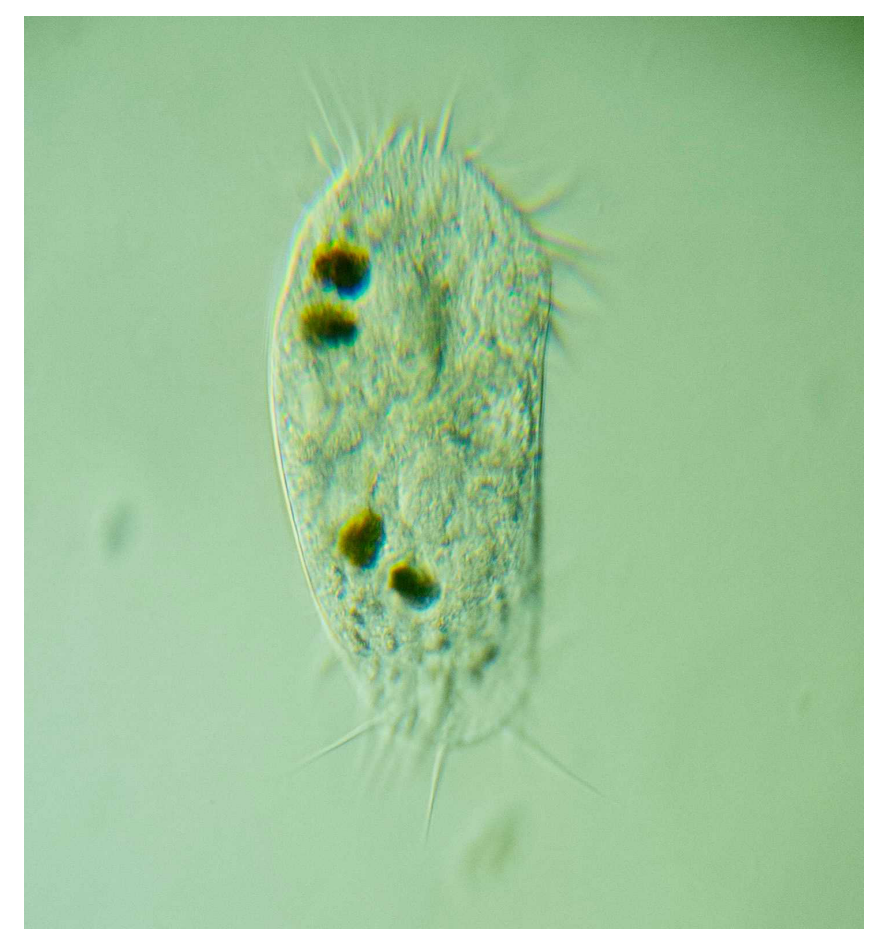

Figure 5. Soil protozoa.

Credits: Wikipedia.org

In addition to microorganisms, the soil food web also includes larger organisms. These include the following:

Earthworms play an important role in soil health by consuming organic matter and producing worm castings, which increase soil organic matter levels. Their tunneling and burrowing through the soil creates pathways for oxygen and water to reach deeper into the soil. A lack of earthworms is also an indication that there may be an absence of protozoa. Protozoa are the primary food source for earthworms, and without a food source, earthworms cannot persist in the soil.

Arthropods have jointed legs, are larger than microarthropods, and can often be seen without magnification. Examples of arthropods that live in or on the soil include beetles, ants, millipedes, centipedes, sowbugs, termites, spiders, mites, and roaches. These animals may consume organic matter or plant roots or feed on other organisms that feed on plant roots.

Crustaceans that dwell in the soil are commonly known as roly-polies or pill bugs. They consume plant material, thereby increasing soil organic matter.

In summary, the soil food web is supported by carbohydrates that plants exude from their roots, providing a source of carbon/energy for the microbes. In this symbiotic relationship, the plants benefit from the activities of the microbes living in the rhizosphere by obtaining the 
nutrients made available by the microbes. The microbes benefit from the carbohydrates, which are their food source, provided by the plant roots. Soil microbes consume organic matter, minerals, nutrients, and each other. The minerals, nutrients, and water that are stored in their bodies are then released again as they decompose, becoming available for plant use.

\section{The Relationship between Organic Matter and Soil Health}

Many gardeners know that the addition of organic matter is beneficial for sandy soil. The presence of organic matter increases both the nutrient and water holding capacity of the soil, which can result in reduced irrigation needs and improved water quality due to nitrogen and phosphorus being held in the soil and stopped from accumulating in the groundwater or running off during rain events. An increase of just $1 \%$ in the organic matter content of the soil can result in the absorption of up to 25,000 gallons of available soil water per acre (Emerson, 1995). Organic matter is also a food source for the soil microbes. It is important to realize that the addition of organic matter to the soil will not have a permanent effect without the presence of a soil food web capable of continually recycling nutrients and organic matter. For additional information on soil organic matter, refer to the EDIS document Raising Soil Organic Matter Content to Improve Water Holding Capacity.

\section{Landscape Practices That May Not Support Soil Health}

There are many landscaping practices that may not support soil microorganisms or a diverse soil food web. Here is a list of some of the most common practices that are not in the best interests of a healthy residential landscape:

- Collecting the grass clippings when mowing and throwing them out in the yard "trash," which keeps them from falling on the lawn and providing both organic matter and nutrients back to the soil. Allowing the grass clippings to fall on the lawn is one of the easiest things that can be done to increase organic matter and return nutrients back to the soil to support the soil food web.

- Disturbing the soil by repeatedly tilling or digging can kill soil microbes. The detrimental effect when the soil is disturbed is that large amounts of oxygen enter the soil, which causes a rapid loss of organic matter through oxidation.
- Fertilizing without soil testing first can result in the overapplication of nutrients, as well as effecting potentially detrimental changes to soil $\mathrm{pH}$. Soil $\mathrm{pH}$ is one factor that can influence the composition of the soil food web, as bacterial and fungal groups prefer a specific $\mathrm{pH}$ range. In addition, high levels of phosphorus will inhibit the colonization of plant roots by mycorrhizal fungi, so monitoring the levels of phosphorus before fertilizing will keep overapplications from occurring (Hicks et al. 1987)

- Leaving the soil bare creates a food desert for the soil microbes. In the absence of plant roots, which would produce root exudates, microbes do not have access to adequate food supplies and have a harder time surviving.

- Removing yard debris is essentially removing important organic matter. Many areas have "yard trash" pickup throughout Florida, but ironically, those same homeowners who use that service make trips to the garden center to purchase compost for their gardens. Instead of hauling out the "yard trash" and placing it by the curb, use it to create a compost pile or cut/chip it up and use it as mulch. For additional information on composting, check out the UF/IFAS EDIS publication Tips for the Home Gardener.

\section{Landscape Practices That Support Soil Health}

The following practices will help to improve and maintain soil health.

- Routinely test the soil, either yearly or every other year, for $\mathrm{pH}$, phosphorus, potassium, magnesium, and the percentage of organic matter. Aim to build the soil's organic matter level up to $5 \%-10 \%$ to support a healthy soil food web. Soil samples can be submitted to the UF/ IFAS Extension Testing Laboratory, and more information about soil sampling for residential landscapes can be found in the EDIS document Soil Sampling and Testing for the Home Landscape or Vegetable Garden.

- Increase the diversity of plant material throughout the landscape, including the lawn. A more diverse plant community will be more resistant to weeds (Simmons et al. 2011), insect pests (Gardiner et al. 2009), and disease (Dunn et al. 2002).

- Cover the soil using mulch, grass, ground covers, or cover crops throughout the landscape. The only exception to this practice would be to provide a small sunny area (e.g., 3' x 3') of bare soil for butterflies to obtain water and minerals from moist sand, called "puddling" 
(USDA-NRCS 2004), and for solitary bees to create tunnels in the ground to lay their eggs.

- Minimize soil disturbance. Tilling and digging will harm mycorrhizae and other soil microbes (Kabir et al. 1997). Repeatedly driving and/or parking on the soil will compact it, reducing the oxygen levels in the soil, leading to the suffocation of the microbes and reducing water infiltration into soils.

- Cultivate living roots that will supply soil microbes with carbohydrates from root exudates. This can be accomplished by growing a variety of plants together, as opposed to having mass plantings of just a few types of shrubs or plants in an area with mulch covering the soil between the plants. Here in Florida we can grow plants throughout the year to keep soil microbes well fed.

- Use organic fertilizer to support the soil microbes when nutrients are needed. Organic fertilizers benefit the soil because: they are a source of organic matter; the nitrogen in organic fertilizers is typically released more slowly, reducing the potential for runoff or leaching; they are not made of salts, which can harm the soil microbes; and because many of the organic fertilizers also contain soil microbes.

\section{- Inoculate the soil with beneficial microorganisms.} Many organic fertilizers also contain beneficial bacteria and mycorrhizal fungi. For example, the Glomus species of endomycorrhizae have a symbiotic relationship with St. Augustinegrass which would benefit the lawn. There are also liquid products that can be used to inoculate the soil with beneficial microbes.

- Add organic matter throughout the landscape. A quick way to stimulate the soil food web is to add organic matter, which is a food source for the SFW, to the soil. For example, top-dressing the lawn with compost can have benefits for turf. Compost also commonly contains beneficial microbes, allowing for the development of internal organic matter and nutrient cycling. Soil structure can thus be built with help from the mycorrhizal and bacterial members of the soil food web.

\section{Summary}

We can follow nature's lead when caring for our plants by restoring and maintaining a healthy, diverse soil food web. Forests and other natural ecosystems grow fine without human intervention. The organic matter that falls in every natural ecosystem stays there, and the soil microbes repeatedly recycle the nutrients. A worthy goal of everyone who cares for land would be to create and maintain a favorable habitat for the soil food web to improve soil health.

\section{References}

Bhadha, J. H., J. M. Capasso, R. Khatiwada, S. Swanson, and C. LaBorde. 2017. Raising Soil Organic Matter Content to Improve Water Holding Capacity. SL447. Gainesville: University of Florida Institute of Food and Agricultural Sciences. http://edis.ifas.ufl.edu/ss661.

Bhadha, J. H., J. M. Capasso, R. S. Schindelbeck, and A. R. Bacon. 2017. Tools for Evaluating Soil Health. SL443. Gainesville: University of Florida Institute of Food and Agricultural Sciences. http://edis.ifas.ufl.edu/ss657.

Brown, S. P. 2017. Compost Tips for the Home Gardener. ENH1065. Gainesville: University of Florida Institute of Food and Agricultural Sciences. http://edis.ifas.ufl.edu/ ep323.

Dunn, J. H., E. H. Ervin, and B. S. Fresenburg. 2002. Turf Performances of Mixtures and Blends of Tall Fescue, Kentucky Bluegrass, and Perennial Ryegrass. HortScience 73:214-217.

Eisenhauer, N., H. Bebler, C. Engels, G. Gleixner, M. Habekost, A. Milcu, S. Partsch, A. C. W. Sabais, C. Scherber, S. Steinbeiss, A. Weigelt, W. W. Weisser, and S. Scheu. 2010. Plant diversity effects on soil microorganisms support the singular hypothesis. Ecology Applications. 91: 485-496.

Emerson, W. W. 1995. Water Retention, Organic Carbon, and Soil Texture. Australian Journal of Soil Research 33: 241-251. Kansas State Extension Agronomy e-update, Number 357, July 6, 2012.

Gardiner, M. M., D. A. Landis, C. Gratton, C. D. DiFonzo, M. O’Neal, J. M. Chacon, M. T. Wayo, N. P. Schmidt, E. E. Mueller. 2009. Landscape diversity enhances biological control of an introduced crop pest in the north-central USA. Ecological Applications. 19: 143-154.

Hicks, P. M., and T. E. Loynachan. 1987. Phosphorus Fertilization Reduces Vesicular-Arbuscular Mycorrhizal Infection, and Changes Nodule Occupancy of Field-Grown Soybean. Agronomy Journal. 79: 841-844.

Kabir, Z., I. P. O’Halloran, and C. Hamel. 1997. Overwinter Survival of Arbuscular Mycorrhizal Hyphae Is Favored by Attachment to Roots but Diminished by Disturbance. Mycorrhiza. 7: 197-200.

Pyle, C. 2004. Butterfly Habitat Components. Available at: https://www.nrcs.usda.gov/Internet/FSE_DOCUMENTS/ nrcs142p2_010828.pdf. Accessed on 1/3/2019. 
Shober, A. L., and R. Mylavarapu. 2018. Soil Sampling and Testing for the Home Landscape or Vegetable Garden. SL281. Gainesville: University of Florida Institute of Food and Agricultural Sciences. http://edis.ifas.ufl.edu/ss494.

Simmons, M., M. Bertelsen, S. Windhager, and H.

Zafian. 2011. The performance of native and non-native turfgrass monocultures and native turfgrass polycultures: An ecological approach to sustainable lawns. Ecological Engineering 37:1095-1103.

Soil Mycorrhizal Course. 2015. Mycorrhizal Symbiosis. https://conference.ifas.ufl.edu/gardener15/documents/Presentations/1\%20Mon\%201300\%20C1\%20A\%20Agely\%20 REVISED2.pdf.

Tugel, A. J., A. M. Lewandowski, and D. Happe-vonArb, eds. 2000. Soil Biology Primer. Ankeny, IA: Soil and Water Conservation Society.

UF/IFAS Extension Testing Laboratory-http://soilslab.ifas. ufl.edu/ESTL\%20Home.asp. 